\title{
Dimensioning of hospital nursing personnel: study with brazilian official parameters of 2004 and 2017
}

\author{
Dimensionamento de pessoal de enfermagem hospitalar: estudo com parâmetros oficiais brasileiros de
} 2004 e 2017

\section{Dimensionamiento de personal de enfermería hospitalaria: estudio con parámetros oficiales brasileños de 2004 y 2017}

Raíssa Ottes Vasconcelos ${ }^{1}$ Denise de Fátima Hoffmann Rigo ${ }^{2}$ Luis Guilherme Sbrolini Marques² Anair Lazzari Nicola²

Nelsi Salete Tonini ${ }^{2}$

João Lucas Campos de Oliveira²

1. Universidade Federal de Santa Maria.

Santa Maria, Rio Grande do Sul, Brazil.

2. Universidade Estadual do Oeste do Paraná.

Cascavel, Paraná, Brazil.
Corresponding author:

Raíssa Ottes Vasconcelos.

E-mail: raissa_07@msn.com

Submitted on $04 / 28 / 2017$.

Accepted on $08 / 22 / 2017$.

DOI: 10.1590/2177-9465-EAN-2017-0098

\begin{abstract}
Objective: To investigate the dimensions of the nursing team of a hospital unit according to the official Brazilian parameters of 2004 and 2017 and compare the dimensioned conditions to the actual condition existing. Method: A cross-sectional study with data from patients $(n=325)$ hospitalized in the Neurology and Orthopedics unit of a university hospital in Paraná, Brazil. Data from the Patient Classification System related to nursing work, as well as sociodemographic and clinical variables of the clientele were compiled. The dimensioning of the nursing staff followed the Federal Nursing Council Resolutions of 2004 and 2017. Results: The profile of the patients showed predominantly men (66.46\%) hospitalized for Orthopedics (49.58\%). The negative difference of professionals dimensioned compared to the actual condition was more evident for the category of nurses, below both the parameters of $2004(-8)$ and 2017 (-11). Conclusions: The number of nursing staff in the unit was insufficient.
\end{abstract}

Keywords: Personnel Downsizing; Workload; Personnel Management; Nursing; Hospital Nursing Staff.

\section{Resumo}

Objetivo: Dimensionar a equipe de enfermagem de uma unidade hospitalar segundo os parâmetros oficiais brasileiros de 2004 e de 2017 e, comparar os quadros dimensionados ao quadro real existente. Método: Estudo transversal realizado entre junho a setembro de 2016 na unidade de Neurologia e Ortopedia de um hospital universitário do Paraná, Brasil. Compilou-se dados do Sistema de Classificação de Pacientes, relativos à equipe de enfermagem; e, variáveis sociodemográficas e clínicas da clientela $(n=325)$. O dimensionamento de pessoal respondeu às Resoluções do Conselho Federal de Enfermagem nacional de $2004 \mathrm{e}$ 2017. Resultados: O perfil dos pacientes era de homens $(66,46 \%)$ internados pela Ortopedia $(49,58 \%)$. A diferença negativa de profissionais dimensionados em comparação ao quadro real foi mais evidente para enfermeiros, tanto aos parâmetros de 2004 (-8) como de 2017 (-11). Houve superávit de técnicos de enfermagem (+6) pelos parâmetros antigos. Conclusões: 0 quadro de pessoal de enfermagem da unidade é insuficiente.

Palavras-chave: Downsizing Organizacional; Carga de Trabalho; Administração de Recursos Humanos; Enfermagem; Recursos Humanos de Enfermagem no Hospital.

\section{Resumen}

Objetivo: Dimensionar el equipo de enfermería de una unidad hospitalaria según los parámetros oficiales brasileños de 2004 y 2017; comparar los cuadros dimensionados con lo real existente. Método: Estudio transversal, realizado entre junio y septiembre de 2016, en la unidade de Neurología y Ortopedia de un hospital universitario de Paraná, Brasil. Los datos fueron procesados en el Sistema de Clasificación de Pacientes, relativos al equipo de enfermería; y variables sociodemográficas y clínicas de la clientela $(n=325)$. El cálculo del personal de enfermería respondió a las resoluciones del Consejo Federal de Enfermería 2004 y 2017. Resultados: El perfil de los pacientes eran predominantemente hombres (66,46\%) admitidos por Ortopedia (49,58\%). La diferencia negativa de profesionales dimensionados en comparación con lo real fue más evidente para la categoría de enfermeros, tanto a los parámetros de 2004 (-8) como los de 2017 (-11). Conclusiones: El cuantitativo de enfermería en la unidad es insuficiente.

Palabras clave: Downsizing Organizacional (Reducción de Personal); Rutina de Trabajo; Administración de Personal; Enfermería; Recursos Humanos de Enfermería en Hospital. 


\section{INTRODUCTION}

The troubled work dynamic in hospitals implies the need to increase the management practices that can propel the organizations towards strategic positioning in the labor market. In this sense, health institutions, especially hospitals, are increasingly seeking to modernize their managerial actions with the aim of achieving better healthcare outcomes and, at the same time, ensuring their survival in the globalized world of service organizations. ${ }^{1}$

Hospitals are institutions that fulfill a daily requirement for patients with health problems and varying degrees of dependency on care. Thus, in order to promote adequate care, it is necessary to use managerial tools to organize the work process, which can be understood as management techniques applied to define priorities and measure, analyze and design strategies to solve problems experienced in the quotidian. ${ }^{2}$

Several of the management tools found in the hospital dynamic are related to the nursing service, since the category represents the largest contingent of human capital linked to hospital care. Nurses are the only professionals to remain with the hospitalized patient in an uninterrupted manner, ${ }^{3}$ with the nature of their work being related to the managerial dimension. ${ }^{4}$

Among the management tools of the nursing services, the dimensioning of personnel stands out, with this being understood as a method of forecasting nursing human resources to fulfill the needs of the care demands of a particular clientele. ${ }^{5,6} \mathrm{It}$ is based on the mathematical determination which appropriates variables inherent to the organization, to the nursing service, and, mainly, to the characteristics of the clientele, according to the degree of dependency on nursing care, which defines the workload of the care team, this being the main variable to be considered in the dimensioning of personnel. ${ }^{5-7}$

The dimensioning of human resources is a managerial activity that is incumbent on nurses, with regard to personnel forecasting under the quantitative and qualitative approaches. .,6 $^{5}$ This is because, in Brazil, nursing personnel dimensioning does not determine "only" the total number of professionals required to attend the clientele, but also estimates the number of workers in proportion to the professional categories (upper and mid level) of nursing. ${ }^{5,6,8}$

Despite acknowledging the importance of dimensioning, there is evidence that hospital nurses do not strategically/ rationally apply, in their work practice, some variables important to staff dimensioning, such as the measurement of the nursing workload, but rather identify it in a bureaucratic way that is disconnected from the direct care, with only the purpose of complying with routine norms. ${ }^{4}$ Furthermore, the instrumental difficulties and the lack of control over the importance and/or meaning of the dimensioning and its variables can weaken the justification of nurses in the argumentation for hiring personnel necessary in the health institutions. ${ }^{8}$
Reinforcing the rationale for identifying and studying staff dimensioning, it is known that, at the international level, the high workload of the nursing team - commonly associated with the quantitative deficit of professionals - can directly compromise the care quality. It can contribute, for example, to a higher risk of death with the reduction of the proportion of nurses per patient, ${ }^{9}$ increased rates of adverse events, such as pressure injuries, falls, errors in drug administration ${ }^{10}$ and hospital infections, and increased length of hospitalization. ${ }^{11}$ Importantly, too greater workload can contribute to poorer outcomes among nursing human resource management indicators, such as turnover and absenteeism. ${ }^{12}$

In addition to the clear direct relationship between care quality and the qualitative-quantitative adequacy of the nursing staff, it should be mentioned that the publication of a new Resolution ${ }^{-6}$ after more than 10 years using the same parameters ${ }^{-5}$ provides a guiding reference for managers and establishes minimum parameters and the method for dimensioning nursing personnel in Brazil, this being a factor that contributed to the performance of this study.

It was postulated that, in the first semester of 2017, it was scientifically relevant for nursing to investigate dimensioning in the context of the new official Brazilian parameters and also of the old ones, as this may clarify, in a more synthetic and systematic way, the differences between the recommendations. Thus, through studies, it would be possible to identify their potentialities and weaknesses, as well as to scientifically disseminate the recent parameters in Brazil and worldwide.

In view of the above, the question arose: is the nursing team of a hospital unit adequate according to the recommendations of the official Brazilian personnel dimensioning parameters of 2004 and 2017 ? Therefore, the aim was to investigate the dimensions of the nursing team of a hospital unit according to the official Brazilian parameters of 2004 and 2017 and to compare the recommended conditions to the actual existing condition.

\section{METHOD}

This was a descriptive, cross-sectional, quantitative study, using documentary source. It was performed in a priority care unit in Neurology (clinical and surgical) and Orthopedics, with 27 beds for adults of both sexes. The unit is part of a public university hospital located in the state of Paraná, Brazil, which is a regional reference in traumatology, neurosurgery, HIV care and high risk pregnancy, with 210 active beds exclusively of the Brazilian Nation Health System (SUS).

The study was carried out on a historical series of 122 uninterrupted days, comprising the period from June to September 2016. In October of the same year, the data collection was concomitantly performed by three Nursing Management residents, who extracted information recorded in the nursing management worksheets of the study sector, a formal document completed daily by the nurses of all shifts and compiled monthly 
by the Nursing Director of the institution. The worksheets include productivity data of the nursing service of each unit (procedures); absenteeism; occupation of the sector; and characterization of the clientele by degree of care dependency.

From the documents mentioned, the following data were collected: quantity of professionals present working in the unit; patient occupation; and the degree of dependence on nursing care of the clientele, measured by the Patient Classification System (PCS) ${ }^{13}$ used in the sector, which was applied daily to all patients by the unit nurses or resident nurses, all of whom were previously trained for this purpose by the sector coordination. Furthermore, sociodemographic and clinical variables of the hospitalized patients were collected from the electronic medical record, such as: sex, age and hospitalization medical specialty.

The SCP ${ }^{13}$ was instituted in its electronic form in 2012, and corresponds to the daily evaluation of each patient according to the degree of dependence on nursing care, through the following criteria/domains: mental state, oxygenation, vital signs, motility, ambulation, feeding, body care, elimination, therapy, cutaneousmucosal integrity, dressing, and time of performing the dressing. Each criterion is assigned a score that corresponds to the degree of dependence of the patient regarding the care domain. ${ }^{13}$

The application of the SCP on schedule generates a score for the evaluated patient. From the score obtained, each patient is classified according to the degree of nursing care dependency, such as: minimal care (12 to 17 points); intermediate care (18 to 22 points); high dependency care (23 to 28 points); semiintensive care (29 to 34 points); and intensive care (over 34 points).$^{13}$ The classification of patients varies according to the requirement for care needs and also the clinical conditions of the individual, representing an increasing scale of severity. ${ }^{13}$ This is an instrument that supports the decisions of nurses in the planning of the care and, especially, in measuring the nursing workload. $5,6,8,13$

Based on the application of the SCP, it was possible to obtain the workload of the nursing team according to the official parameters that govern the dimensioning of personnel in Brazil. Accordingly, Resolution 293/2004 of the Federal Nursing Council $(\mathrm{COFEN})^{5}$ states that minimum care patients are equivalent to 3.8 hours of care/day; intermediate care patients, 5.6 hours of care/day, semi-intensive care patients, 9.4 hours of care/day and intensive care patients, 17.9 hours of care/day. As the 2004 Resolution does not cover high-dependency care patients and the unit used the SCP that assigned this classification, the measurement of hours for this classification was grouped with semi-intensive care nursing $(9.4 \mathrm{~h})$, as this is the procedure adopted in the parameters of the current Resolution, ${ }^{6}$ which generated equality in the two measures of care hours.

Resolution 543/2017 of COFEN ${ }^{6}$ updates these parameters and states that minimum care patients are equivalent to 4 hours of care/day; intermediate care patients, 6 hours of care/day; high dependence care and semi-intensive care patients, 10 hours of care/day; and intensive care patients, 18 hours care/day.
All the data collected were compiled in Microsoft Excel, version 2010, spreadsheets. The sociodemographic and clinical characterization variables were analyzed by descriptive statistics, in measures of proportion. In turn, to obtain the staff dimensioning conditions, the dimensioning methodology was followed, according to the COFEN Resolutions of 2004 and 2017 , using the mean number of patients per day (sum of the historical series divided by the number of days of observation) of each SCP category and the respective nursing hours required, provided by the parameters used. 5,6

In order to perform the calculation, Marinho's constant coefficient was used, which is the same in both resolutions, altering only the respective nursing hours already mentioned. Another aspect in which the calculation methodology differs is the consideration of the mean number of patients proportional to the occupancy rate of the unit in the methodology in the 2004 Resolution to determine the nursing time spent on each category of care, which is unnecessary according to the 2017 method, that is, the mean number of patients is used to estimate the nursing hours. ${ }^{5,6}$

In the design of Marinho's Constant, the total number of nursing hours is calculated by multiplying the daily mean of patients in each category of care according to their respective dependence on care time (hours), followed by the sum of hours of all the care categories, with this total, subsequently, multiplied by Marinho's Constant, which is the coefficient deduced as a function of the available time of the worker and coverage of absences..$^{5,6}$ Therefore, this coefficient already considers the Technical Security Index (TSI) of the nursing staff, which is an addition to the dimensioned condition in order to cover foreseen and unforeseen absences and which was determined as $15 \%$ in this study, this being the minimum recommended in both resolutions. ${ }^{5,6}$

The constant of $0.2236^{5,6}$ was used, which refers to a workday of the nursing team of 36 hours per week, according to the work process of the study site. Thus, the mathematical equation used to dimension the team, based on the parameters of the two resolutions, separately, was: Personnel Condition $=0.2236 \mathrm{x}$ Total Nursing Hours. ${ }^{5,6}$

The proportion of professionals by category (qualitative dimensioning phase) was also used, respecting the differences in each resolution, that is, the percentage of the total dimension of nurses and mid-level professionals was determined according to the category of care (degree of dependency) more prevalent among the clients (parameters of 2004) and the one with the greatest workload demand (parameters of 2017), that is, hours of care required. ${ }^{5,6} \mathrm{As}$ the Resolution of $2004^{5}$ presents a percentage interval of nurses in the dimensioned condition, it was decided to use the maximum recommended by the regulations.

The study was developed in full compliance with the ethical requirements set forth in Resolution 466/2012 of the National Health Council. For this, the Research Project that includes this investigation was submitted to the Human Research Ethics Committee of the State University of the West of Paraná, and 
accepted under authorization No. 1.450.491/2016 and CAAE: 53129516.2.0000.0107.

\section{RESULTS}

The sample of the clientele attended was composed of 325 patients. These were predominantly male (66.16\%), with a prevalent age group above 60 years of age (37.21\%). Regarding medical specialties, the majority $(49.53 \%)$ of the clientele were hospitalized for orthopedics. In the period studied, the occupation rate of the unit was $81 \%$.

Despite considering a unit aimed, in theory, at Neurology and Orthopedics, it was observed that 38 patients hospitalized were of other medical specialties. These and other characterization data from the patient sample are summarized in Table 1.

Table 2 presents the number of patient classifications per month of observation, as well as the mean number of patients per day in each category of care. These values represent the classifications of every day of each month, therefore, they differ from the total of hospitalized clients in the period, since the same patient was counted several times throughout their hospitalization.

Table 1. Sociodemographic and clinical characteristics of the patients $(n=325)$ hospitalized in a Neurology and Orthopedics unit. Cascavel - PR, Brazil, 2016.

\begin{tabular}{lcc}
\hline Variable & Categories & $\mathbf{N}(\%)$ \\
\hline Sex & Female & $109(33.54)$ \\
& Male & $216(66.46)$ \\
\hline Age groups & 27 to 37 years & $55(16.92)$ \\
(years) & 38 to 48 years & $36(11.07)$ \\
& 49 to 59 years & $64(15.07)$ \\
& $>60$ years & $121(37.24)$ \\
\hline & Orthopedics & $161(49.58)$ \\
& Neurology & $116(35.69)$ \\
Angiology/Vascular Surgery & $10(3.07)$ \\
specialty & Cardiology & $3(0.92)$ \\
& Maxillofacial surgery & $1(0.30)$ \\
& General surgery & $11(3.40)$ \\
& Plastic surgery & $1(0.30)$ \\
& Thoracic surgery & $1(0.30)$ \\
& General Clinical & $9(2.76)$ \\
& Clinical Medical & $7(2.15)$ \\
& Endocrinology & $3(0.92)$ \\
& Gastroenterology & $2(0.61)$ \\
\hline
\end{tabular}

Based on the mean daily number of patients in each care dependency category, it was possible to estimate the number of nursing care hours required by the mean number of patients, both based on the 2004 parameters, which totaled 155.3 hours, and on the 2017 parameters, which gave a total of 202.68 hours. The ratio of nursing hours per care category is shown in Table 3.

The prevalent care dependence category and increased workload demand was semi-intensive care, which determined the proportion of workers by professional category of nursing in the dimensioning, for both the 2004 and 2017 parameters. Therefore, Box 1 illustrates the comparative analysis between the personnel conditions dimensioned, by both parameters, and the actual one in the unit.

\section{DISCUSSION}

Regarding the characterization of the hospitalized patients $(n=325)$, the male gender and the age group of 60 years and over were predominant. Although it is not possible to make strong inferences about these findings, it is believed that this profile is linked to the care specialty of the unit, that is, Neurology and Orthopedics. This is because, orthopedic care, more prevalent $(49.58 \%)$ than neurosurgery in the study, is usual in the treatment of fractures and victims of trauma, which have a direct relation with automobile accidents and other external causes, such as violence and accidents at work, these being more commonly found among men in the Brazilian context.

The previous assumption supports the fact found in a national epidemiological study that confirms that mortality due to external causes in Brazil is much higher among males, since the coefficient of the indicator found in the research carried out with data from the year 2010, resulted in 178 per 100,000 inhabitants among men, compared to 24 per 100,000 inhabitants among women. ${ }^{14}$

Regarding the age of the patients investigated, a similar result was obtained from a study performed in a general hospital in São Paulo, in which $62 \%$ of the participants were men and the mean age was 61 years. ${ }^{15}$ Another study, carried out in a clinical medical unit of a regional hospital in Belo Horizonte, showed the majority of the participants to be men, with a mean age of 62 years.

It should be mentioned that age is not a measurement factor in the PCS,$^{13}$ however, due to the natural process of senility, long-term patients are expected to be more dependent on care, whether this is of a clinical-interventional nature or for daily activities, which probably - to a greater or lesser degree - will undergo changes in the hospitalization regime. ${ }^{16}$ Thus, although the unit studied was not characterized as a semi-critical care sector, the highest concentration of clientele was classified, with both the dimensioning parameters of 2004 and 2017, as having semi-intensive care dependency, a fact directly linked to the increase in the workload of the nursing team in the sector. 
Table 2. Quantity of hospitalized patients per month and daily mean of patients in relation to the degree of care complexity determined by the Patient Classification System (PCS). Cascavel - PR, Brazil, 2016.

\begin{tabular}{|c|c|c|c|c|c|}
\hline Month & Minimal care & Intermediate Care & High Dependency Care & Semi-Intensive Care & Intensive Care \\
\hline June & 105 & 154 & 165 & 187 & 77 \\
\hline July & 56 & 112 & 201 & 220 & 55 \\
\hline August & 61 & 94 & 264 & 205 & 44 \\
\hline September & 119 & 117 & 157 & 271 & 37 \\
\hline Mean* & 2.79 & 3.90 & 6.45 & 7.23 & 1.74 \\
\hline Mean $x \mathrm{OR}^{* *}$ & 2.25 & 3.15 & 5.22 & 5.85 & 1.40 \\
\hline
\end{tabular}

Table 3. Nursing hours required for the patients per day, by care dependency category, according to the official Brazilian parameters of 2004 and 2017. Cascavel - PR, Brazil, 2016.

\begin{tabular}{cccccc}
\hline Parameter & Minimal care & Intermediate Care & High Dependency Care & Semi-Intensive Care & Intensive Care \\
\hline 2004 & 8.55 & 17.64 & 49.06 & 54.99 & 25.06 \\
2017 & 11.16 & 23.40 & 64.50 & 72.30 & 31.32 \\
\hline
\end{tabular}

Box 1. Comparison between the nursing staff dimensions by the parameters of the COFEN 2004 and 2017 Resolutions and the actual one in the Neurology and Orthopedics unit. Cascavel - PR, Brazil, 2016.

\begin{tabular}{lcccc}
\hline Personnel condition & Nurses & Nursing Technicians and/or Assistants & Total \\
\hline Actual & 8 & 25 & 33 \\
\hline Dimensioned - Resolution 2004 & 16 & 19 & 35 \\
Dimensioned - Resolution 2017 & 19 & 26 & 45 \\
\hline
\end{tabular}

The problem mentioned, namely: hospitalization of critically ill patients, or, those highly dependent on care, in units theoretically unprepared for such care, has already been verified in other studies on the measurement of the degree/level of care complexity of patients under the care of the nursing team, in a non-critical unit in a surgical medical clinic in the interior of Paraná ${ }^{17}$ and in a sector that was not intended for the semi-critical or critical care of surgical patients in the capital of Rio Grande do Sul. ${ }^{18}$ It is believed that the studies cited used two distinct PCSs, which reinforces, with more evidence, that the problem is a reality to be faced by the hospital leadership.

Patients classified as dependent on semi-intensive care do not necessarily have hemodynamic and/or ventilatory instability and are not normally at imminent risk of death, a characteristic common to intensive care patients. ${ }^{13}$ However, knowing the clinical profile of the sample of this study, it was conjectured that a greater proportion of the clientele would require this level of care due to impaired mobility; need for direct and continuous support of the nursing team for body hygiene; eliminations while restricted to the bed and/or attached to care devices, such as delayed bladder catheter; and possibly due to the need for extensive dressings. These characteristics are related to the care common among post-surgical patients, who comprise the majority in the medical specialties of Orthopedics and Neurosurgery, and possibly amplified the workload of the nursing team with the increase of care hours required daily.

With the increase in the workload of the nursing team, if it is accompanied by a deficit of human resources provided by the management, it is common to find under-dimensioning of care providers. ${ }^{8}$ This is alarming because, although an adequate number of professionals does not guarantee higher quality nursing care, increases in workload have already been clearly associated with worse care outcomes, such as the increase in infections associated with catheters, falls, and even higher mortality. ${ }^{12,19}$

A study of 65 hospitals in South Korea, which aimed to investigate the association of nursing staff and overtime with patient safety and the perception of the nursing team regarding the care quality and the care neglected, found that adequacy of the nursing staff is imperative for care quality and safety, as well as to reduce the amount of care neglected by the care team..$^{20}$

The total nursing staff dimensioning condition was insufficient, compared to the actual, through measurement by both parameters and their respective guiding Resolutions. ${ }^{5,6}$ Comparing these with the actual nursing staff condition presented in the unit, it was verified that there was an important deficit of nurses, 
with negative differences, both in $2004(-8)$ and in $2017(-11)$. For the mid level category of workers, the dimensioning through the 2004 parameters presented a surplus of six workers; and, according to the current parameters, there was a deficit of "only" one nursing technician professional.

The clear deficiency of nurses in the unit studied was most likely a product of the lack of monitoring by the management of the hiring of additional staff in the sector, considering the care profile in the unit, as the demand for semi-intensive care prevalent in the unit is known. For this category of care, the 2004 COFEN resolution recommends 42 to $46 \%$ (used in this study) as the minimum proportion of nurses. The current legislation determines a single value in $42 \%$ for this category. ${ }^{6}$ It is considered that the update, even with a decrease in the proportion of nurses, maintained a satisfactory relationship of the professional category and, in addition, standardized a single percentage value, favoring, possibly, the inspection actions by competent agencies.

Another important difference between the Resolutions and their respective methodologies for calculating nursing staff dimensioning is the consideration, in 2004, of the occupancy rate of patients to proportionally calculate the mean number of clients per day in the care unit, ${ }^{5}$ which notoriously attributed lower value to the means of all categories of care (Table 2). This is relevant and it is commendable that the Resolution in force in 2017 has abandoned this methodology, since, the simple mean of patients measured in a historical series of use of the PCS probably already reflects the proportion of clientele occupancy in the service to be dimensioned in an accurate way, not interfering in a negative way (reducing) the definition of the staff framework to provide care, as in the methodology of 2004.

The deficit of nurses is a problem that draws attention to the work class, since this tends to hinder the performance of the professional towards the strategic and rational management of individualized care and also the direct care for patients with greater dependency and/or care complexity. This fact can contribute to a reality of bureaucratization and even the invisibility of their work, that is, performance that is not closely linked to the actual needs of the assisted clientele, represented by the overload of activities unrelated to care and its inputs. The significant decrease in nurses will invariably increase the workload of nursing technicians and assistants and may contribute to job dissatisfaction, absenteeism and staff turnover. ${ }^{12}$

Similarly, the surplus of nursing technicians, verified in the dimensioning according to the parameters of 2004, reinforces that the hospital organization tends to substitute the human capital most qualified to provide the care needs of a complex clientele, in terms of care dependency. It is not necessary to question the ability of the technical team to provide qualified and safe care, however, it should be highlighted that nursing, as a profession and science, needs to review the clarity of how the care team will be formed for patients with higher levels of complexity. Furthermore, this may impact negatively on the economic and social factors of the category of nurses, such as unemployment. Thus, it is postulated that this reaffirms the need for nurses to strategically use the measures and tools of management, such as dimensioning. ${ }^{8}$

In a study that aimed to analyze the use of nursing care management measures in hospital units, it was found that nurses rarely strategically use these measures and tools, as they are immersed in the organizational dynamics, full of institutional demands, that are not always related to the management of care, which should be at the heart of their profession. ${ }^{4}$ Considering that the qualitative study mentioned above did not aim to investigate the relationship between the use of care management and the proportion of nurses per hospital unit, it is necessary to highlight these issues, including them in future investigations.

In addition to the problem of interest of the nurses themselves, the fact is verified by a study of American origin that affirmed that seriously ill patients assisted by a higher proportion of nursing professionals with bachelor's degrees (this being related to the level of nurse in Brazil) are significantly less exposed to the risk of dying. ${ }^{21}$ However, it is evident that the negative difference in the category of nurses observed according to the Brazilian dimensioning parameters of both 2004 and 2017 is a problem that deserves more attention for the possible professional recognition, as well as for the best quality of care.

The result evidenced in the study in question contrasts with studies performed in ICUs of a hospital in Pernambuco, where during the daytime period there were no deficits in nurses..$^{22}$ This finding leads to the reflection that staffing is essentially a method of prediction of human nursing capital that is directly influenced by the management dynamics and philosophy of each health organization, demonstrating the need to be vigilant to the requirement of additional personnel in compatibility with the organizational reality and resources available, having the quality of care as the focus of the management actions. ${ }^{8}$

This corroborates the allusion expressed in a recent national study, in which data of the care and management indicators of interest in the nursing service of a non-critical hospital unit were compared after an adjustment/increase of $40 \%$ in the total number of nurses and $16 \%$ in nursing technicians, showing a $75 \%$ reduction in pressure injury rates; $10.5 \%$ reduction in falls; and $50 \%$ reduction in infections related to bladder catheterization. ${ }^{3}$ In addition, the study also found that there was a $12.0 \%$ reduction in sick leave, $21.8 \%$ in the total extra hours bank, and $92.0 \%$ reduction in overtime paid, ${ }^{3}$ indicators not only of interest to the care but also to the survival of institutions in the competitive healthcare market today.

In view of the above, considering the under-dimensioning of the nursing staff in the team studied, it should be mentioned that it is prudent that the representative bodies and entities of the work class, at the local/institutional level and in their coverage of nursing as a profession, promote actions not only for inspection, 
but also for the political agenda with regard to dimensioning as a factor for promotion of the quality of care and better working conditions of nursing.

\section{CONCLUSIONS AND IMPLICATIONS FOR PRACTICE}

It was concluded that the staff condition of the study unit was insufficient both according to the condition dimensioned by the parameters of 2004 and that of 2017. In both cases, there was an evident deficiency of nurses. According to the recommendations of 2004, there was a surplus of nursing technicians, and the category was very close to adequacy according to the current parameters. The parameters of 2017 , due to the increase in nursing hours required and the non-consideration of the occupancy rate in the definition of the proportional mean of patients per day, tend to emphasize the disparity between the values of the actual personnel quantity and the dimensioning, this being a didactic contribution of this study. In practice, it is likely that the 2017 parameters more faithfully represent the workload of Brazilian hospital nursing, or at least favor more dignified work conditions.

The purely descriptive content and the geographical restriction can be considered limitations of this study. However, the study includes a very relevant diagnosis for the management of the nursing team in Neurology and Orthopedics sectors, as well as demonstrating a comparison between the official Brazilian parameters, an action necessary due to the current legislation. Not least, it is believed that the study contributes greatly to the systematic observation that hospital leaders need to review the distribution of personnel, both quantitatively and qualitatively, in non-critical sectors where patients with a high demand for care are hospitalized.

\section{ACKNOWLEDGMENTS}

Financial support from the State University of West of Paraná for the translation of the manuscript.

\section{REFERENCES}

1. Santos JLG, Pestana AL, Guerrero P, Meirelles BSH, Erdmann AL. Nurses' practices in the nursing and health care management: integrative review. Rev Bras Enferm [Internet]. 2013 Mar/Apr; [cited 2017 Jan 1]; 66(2):25763. Available from: http://www.scielo.br/pdf/reben/v66n2/16.pdf

2. Schmoeller R, Gelbcke FL. Indicators for the measurement of emergency personnel. Texto Contexto Enferm [Internet]. 2013 Out/Dec; [cited 2017 Jan 5]; 22(4):971-9. Available from: http://www.scielo.br/pdf/tce/v22n4/ en_13.pdf

3. Quadros DV, Magalhães AMM, Mantovani VM, Rosa DS, Echer IC. Analysis of managerial and healthcare indicators after nursing personnel upsizing. Rev Bras Enferm [Internet]. 2016 Jul/Aug; [cited 2017 Jan 1]; 69(4):684-90. Available from: http://www.scielo.br/scielo. php?script=sci $\_$arttext\&pid=S0034-71672016000400684
4. Vasconcelos RO, Bohrer CD, Rigo DFH, Marques LGS, Oliveira JLC Tonini NS, et al. Means for nursing management used in critical hospital units. Enferm Foco [Internet]. 2016; [cited 2017 Jan 2]; 7(3/4):56-60. Available from: $\mathrm{http}: / /$ revista.portalcofen.gov.br/index.php/enfermagem/ article/view/944/354

5. Conselho Federal de Enfermagem (BR). Resolução COFEN № 293/2004, de 21 de setembro de 2004. Fixa e estabelece parâmetros para dimensionamento do quadro de profissionais de enfermagem nas unidades assistenciais das instituições de saúde e assemelhados. Brasília (DF): COFEN; 2004. [cited 2017 Sep 19]. Available from: http://www.cofen. gov.br/wp-content/uploads/2012/03/RESOLUCAO2932004.PDF

6. Conselho Federal de Enfermagem (BR). Resolução COFEN № 543/2017, de 18 de abril de 2017. Atualiza e estabelece parâmetros para o Dimensionamento do Quadro de Profissionais de Enfermagem nos serviços/locais em que são realizadas atividades de enfermagem. Brasília (DF): COFEN; 2017. [cited 2017 Sep 19]. Available from: http:// www.cofen.gov.br/resolucao-cofen-5432017_51440.html

7. Vieira FPC, Garcia PC, Fugulin FMT. Nursing care time and quality indicators at a pediatric and neonatal Intensive Care Unit. Acta Paul Enferm. [Internet]. 2016; [cited 2017 jan 2]; 29(5):558-64. Available from: http://www.scielo.br/scielo.php?script=sci_arttext\&pid=S0103$21002016000500558 \& \operatorname{lng}=e n \& n r m=i s o$

8. Fugulin FMT, Oliveira JLC, Nicola AL, Araujo ASS, Marinho AM, Canavezi $\mathrm{CM}$, et al. Dimensioning of nursing professionals: implications for the care practice. Rev Divulg Saúde Deb [Internet]. 2016; [cited 2017 Jan 2]; (56):126-33. Available from: https://www.researchgate net/publication/311753919 Dimensionamento de profissionais_de enfermagem_implicacoes_para_a_pratica_assistencial

9. Neuraz A, Guérin C, Payet C, Polazzi S, Aubrun F, Dailler F, et al. Patient mortality is associated with staff resources and workload in the ICU: a multicenter observational study. Crit Care Med [Internet]. 2015 Aug [cited 2017 Jan 2]; 43(8):1587-94. Available from: https://www.ncbi.nlm. nih.gov/pubmed/25867907

10. Oliveira AC, Garcia PC, Nogueira LS. Nursing workload and occurrence of adverse events in intensive care: a systematic review. Rev Esc Enferm USP. [Internet]. 2016; [cited 2017 Jan 2];50(4):679-89. Available from: http:// www.scielo.br/pdf/reeusp/v50n4/0080-6234-reeusp-50-04-0683.pdf

11. Lankshear AJ, Sheldon TA, Maynard A. Nurse staffing and healthcare outcomes: a systematic review of the international research evidence. Adv Nurs Sci. [Internet]. 2005 Apr/Jun; [cited 2017 Jan 2]; 28(2): 163-74 Available from: https://www.ncbi.nlm.nih.gov/pubmed/15920362

12. Magalhães AMM, Dall'Agnol CM, Marck PB. Nursing workload and patient safety - a mixed method study with an ecological restorative approach. Rev Latino Am Enferm [Internet]. 2013 Jan/Feb; [cited 2017 Jan 2]; 21 (no.spe):146-54. Available from: http://www.scielo.br/scielo. php?script=sci_arttext\&pid=S0104-11692013000700019

13. Santos F, Rogenski NMB, Baptista CMC, Fugulin FMT. Patient classification system: a proposal to complement the instrument by Fugulin et al. Rev Latino Am Enferm [Internet]. 2007 Set/Oct; [cited 2017 Jan 2]; 15(5):980-5. Available from: http://www.scielo.br/scielo. php?script=sci_arttext\&pid=S0104-11692007000500015

14. Moura EC, Gomes R, Falcão MTC, Schwarz E, Neves ACM, Santos W. Gender inequalities in external cause mortality in Brazil, 2010. Ciênc Saúde Coletiva [Internet]. 2015 Mar; [cited 2017 Jan 2]; 20(3):779-88. Available from: http://www.scielo.br/scielo.php?script=sci_arttext\&pid $=$ S1413-81232015000300779

15. Marques RS, Zeitoun SS, Lara MR, Fernandes MS. Dimensioning of staff related to patient care using the critical Nursing Activities Score in the ways prospective and retrospective. J Health Sci Inst [Internet] 2013; [cited 2017 Mar 25]; 31(2):149-54. Available from: https://www. unip.br/comunicacao/publicacoes/ics/edicoes/2013/02_abr-jun/ V31_n2 2013 p149a154.pdf

16. Araujo MT, Velloso ISC, Queiroz CF, Henriques AVB. The dimension of the nursing staff of a medical unit. Rev Enferm Cent Oeste Min [Internet] 2016 Mai; [cited 2017 Mar 24]; 6(2):2223-34. Available from: http://www. seer.ufsj.edu.br/index.php/recom/article/view/971 
17. Barbosa HB, Paiano LAG, Nicola AL, Fernandes LM. Complexity level of patient assessment and the amount of professional nursing. Rev Enferm UFSM [Internet]. 2014 Jan/Mar; [cited 2017 Mar 23]; 4(1):29-37. Available from: https://periodicos.ufsm.br/reufsm/article/view/9230

18. Silva KS, Echer IC, Magalhães AMM. Patients dependency degree in relation to the nursing team: a management tool. Esc Anna Nery [Internet]. 2016; [cited 2017 Mar 24]; 20(3):e20160060. Available from: http://www.scielo.br/pdf/ean/v20n3/1414-8145ean-20-03-20160060.pdf

19. Novaretti MCZ, Santos EV, Quitério LM, Daud-Gallotti RM. Nursing workload and occurrence of incidents and adverse events in ICU patients. Rev Bras Enferm [Internet]. 2014 Sep/Oct; [cited 2017 Mar 22]; 67(5):692-9. Available from: http://www.scielo.br/pdf/reben/ v67n5/0034-7167-reben-67-05-0692.pdf
20. Cho E, Lee N, Kim E, Kim S, Lee K, Park K, et al. Nurse staffing level and overtime associated with patient safety, quality of care, and care left undone in hospitals: a cross-sectional study. Int J Nurs Stud [Internet]. 2016 Aug; [cited 2017 Mar 23]; 60:263-71. Available from: http://www. journalofnursingstudies.com/article/S0020-7489(16)30056-6/abstract

21. Kelly DM, Kutney-Lee A, McHugh MD, Sloane DM, Aiken LH. Impact of critical care nursing on 30-day mortality of mechanically ventilated older adults. Crit Care Med [Internet]. 2014 May; [cited 2017 Mar 22]; 42(5):1089-95. Available from: https://www.ncbi.nlm.nih.gov/ pubmed/24368346

22. Mendes RNC, Carmo AFS, Salum RDL, Gusmão-filho FAR, Vidal SA, Santos VEP. Sizing personnel: evaluation of nursing in obstetric and mixed pediatric intensive care units. Rev Pesq Cuid Fundam Online [Internet]. 2013 Apr/Jun; [cited 2017 Mar 20]; 5(2):3706-16. Available from: http://www.seer.unirio.br/index.php/cuidadofundamental/article/ view/2262/pdf_762 